\title{
Islamic Scriptures and Voice Intonation: A Preliminary Survey in Arabic Linguistic Thought and Hadīth Interpretive Discourse
}

\author{
KHAIRIL HUSAINI BIN JAMIL \\ Kulliyyah of Islamic Revealed Knowledge and Human Sciences, International Islamic University \\ Malaysia, 53100 Kuala Lumpur, Malaysia \\ husaini@iium.edu.my
}

Published online: 15 August 2019

To cite this article: Khairil Husaini bin Jamil. 2019. Islamic scriptures and voice intonation: A preliminary survey in Arabic linguistic thought and hadīth interpretive discourse. KEMANUSIAAN the Asian Journal of Humanities 26(Supp.1): 1-21. https://doi.org/10.21315/ kajh2019.26.s1.1

To link to this article: https://doi.org/10.21315/kajh2019.26.s1.1

\begin{abstract}
This is the first study that aims to explore the possibility of applying the art and science of voice intonation in reading statements attributed to the Prophet Muhammad and to form a theoretical framework explicative of the nexuses between the two enterprises. The study ventures to assess the attention towards a range of functions played by voice intonation such as attitudinal functions, psychological functions and other indicative functions as it may have appeared within the various compositional strategies of hadith literature. It also aims to examine how normal conversations, declarative sentences, questions, etc. could be identified through voice intonation and the extent to which the understanding of a certain hadith can be affected by such an exercise. The preliminary analysis indicates that the right selection of tone assumes a crucial role in forming a sound hadith interpretation. The consequential extension of this study may involve several other subtopics in the field such as the oral and written transmission of hadith, the euphony and cacophony of narrated words and sentences in hadith, and the psycho-spiritual effects of hadith.
\end{abstract}

Keywords and phrases: intonational meaning, hadìth interpretation, hadìth linguistics, matan criticism, scriptural phonology

\section{Introduction}

"Yasin dan Sulaiman pergi menghadiri seminar berkenaan hadìth di Istanbul". This Malay sentence can be intoned variably based on different contexts. If the sentence were to be a response to a nonpolar question, several emphases could be expected following the use of different interrogative words (wh-questions). The following (A 1-4) represents possible cases that exemplify the above proposition, with the emphases and risings in intonation indicated by the capitalisation: 
A. Yasin dan Sulaiman pergi menghadiri seminar berkenaan hadìth di Istanbul.

1. Who: Siapakah yang pergi menghadiri seminar berkenaan hadìth di Istanbul? = YaSIN dan SulaiMAN (yang) pergi menghadiri seminar berkenaan hadīth di Istanbul.

2. What: Apakah yang dilakukan oleh Yasin dan Sulaiman di Istanbul? = Yasin dan Sulaiman pergi menghadiRI semiNAR berkenaan hadith di Istanbul.

3. What: Yasin dan Sulaiman pergi menghadiri seminar berkenaan apa di Istanbul? = Yasin dan Sulaiman pergi menghadiri seminar berkenaan HADĪTH di Istanbul.

4. Where: Yasin dan Sulaiman pergi menghadiri seminar berkenaan hadith di mana? = Yasin dan Sulaiman pergi menghadiri seminar berkenaan hadìth di ISTANBUL.

Cases such as the above constitute an instance conventionally qualified as the essence of "focusing" (Büring 2016). Focusing, occasionally rendered as accentual or informational in English phonetics, constructs one of the intonational functions that correspond constantly to the intonation-and-meaning phenomena. According to Büring, a difference in the prosodic realisation of an utterance corresponds in an ostensibly systematic way with a difference in interpretation. This consistently corroborates the fact that the rise and fall of pitch in human voices plays a vital role in how they express meaning. Informational function such as the above could be the most fundamental function in our voice intonation. However, other more specific functions have also been established such as attitudinal function (e.g., expressing emotions and attitudes), grammatical function (e.g., discerning a question from a statement), discourse function (e.g., discerning a subordinate clause from a main clause), psychological function (e.g., imparting a better chance of comprehension) and indexical function (e.g., representing context, background, identity, etc.) (Wells 2006).

This sort of linguistic phenomenon is not exclusive to bahasa Melayu and English. It has also been long visited in Arabic linguistic thought. A classic example often adduced is the following line of al-Farazdaq (c. $114 \mathrm{AH} / 732 \mathrm{CE}$ ):

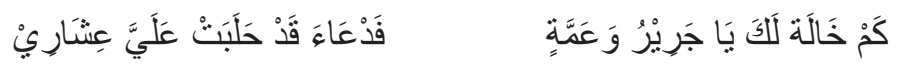

Since the linguist and grammarian of Arabic language Sībuviyē (c. 180 AH/796 CE, Persia) has reported that the ancient native Arabs used the particle kam to denote both an assertion and a question, the above line can be read either as a declarative or as an interrogative one. In the former, the word khälat will take an $i$-case (majrür), 
so as to be read khālatin, while in the latter, it will assume an $a$-case (manșüb), so as to be pronounced khälatan. The meaning changes significantly from asserting that Jarīr has many aunts to asking Jarīr about the number of aunts he has. Although this example shows how grammatical identification affects interpretation, it does implicitly indicate that intonation, especially in poetry, contributes significantly to the outcome.

Moreover, one finds that the attention given by the Muslim Arabs towards intonation is extensive in the field of Qur'anic recitation. The study of maqāmāt (melodic modes) of recitation bears witness to this effort where some sort of musicality such as the use of melody and vocal artistry are required to induce an ideal recitation (Rasmussen 2001). The recitation of the Qur'ān, however, is regarded by Muslim scholars and the public as a separate art, mainly to distinguish it from the art of other religious and secular music, although certain overlaps in ornamentation, terminology, emotional and physical responses, and aesthetic and economic standards have been observed. This is to maintain the divine identity, perfection and uniqueness of the text and to avoid reducing it to the status of entertainment (Nelson 2001). This traditional bifurcation can also be perceived from the centuries-old debate on the status of $\operatorname{sam}_{\bar{a}}{ }^{\prime}$ that concerns both the status of religious and devotional songs and music, and the status of music per se in Islamic rulings (A1-Judaie 2005).

Notwithstanding that, voice intonation has been identified by the Qur'anic exegetes as an instrumental agency to gauge the possible meanings of a Qur'anic verse, especially one that accommodates multiple qirā' $\bar{a} t$ (variant readings). As an example, when commenting on the Qur' anic verse of al-A 'rāf 7:123, Abū 'Alī al-Fārisī (377 AH/988 CE) indicated that the word آمنتم (āmantum) has been read by the qurra ' (readers) in the sense of either interrogative or declarative (Al-Fārisī 1993). From a comparison between 35 English translations of the Qur'ān, it is learned that five of them left the translated sentence without a question mark. The other five finished it with an exclamation mark and the rest clearly assumed it as a question. Taking it as a declarative sentence, the verse will translate as: "Pharaoh declared, 'You have believed in Him before I permit you. This is a plot you...", whereas reading it as a question yields: "Pharaoh said, 'How dare you believe in Him before I have given you permission? This is a plot you..." Thus, in reading the Qur'anic text (al-A 'rāf 7:123),

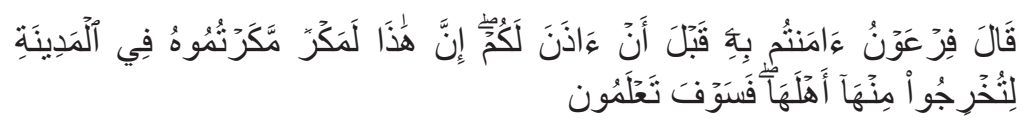

the use of high pitch in reciting the word amantum (ََ) is taking it as a question, while the low pitch implies that it is a mere assertion. 
The field of Qur'anic studies may have conditioned this subject under several areas of subdisciplines, i.e., the science of tajwìd, the science of qirā 'a $\bar{t}$, the art of tarannum, etc. It had also been forwarded that the attention towards tones and melodies in this area was motivated by the Prophetic tradition that says: "He is not of us who does not chant pleasingly with the recitation of the Qur'ān" (Al-Bukhārī, hadīth no. 7527), and the Prophet's remark of his companion, Abū Mūsā's recitation as "being endowed with a Davidian windpipe - attributed to the Prophet David's family" (Al-Bukhārī, hadīth no. 5048).

On the other hand, hadith texts too have been appropriated as scripture in Islamic thought (Musa 2008). As far as the subject of intonation is concerned, a question is worth asking in relation to this second source of Islamic sacred texts - was there any study on the tanghim (intonation) of the speech of the Prophet?

\section{The Concept of Tanghim (Intonation) in Arabic Linguistic Thought}

Modern Arabic linguistic thought was introduced to the term tanghim by Ibrahim Anis (n.d.) who wrote under the topic mūsiqa al-kalām (the music of speech):

Recent experiments have proven that as a person utters a sentence of his own language, he does not follow a single pitch in producing the sounds. A word that consists of one syllable may differ in its pitch. Likewise, the multi-syllable words. In some languages like the Chinese, the difference in pitches may lead to different meanings ... we may call this changing of levels in pitches as al-naghmah al-müsíqiyyah (musical tune). (Anis n.d., 103)

Earlier, Anis indicated that as human beings speak, there is a change of pitch in almost all syllables that he uttered. However, the range between a pitch to another is not as pronounced as the range between them during an act of singing. Moreover, they are far more extended in English songs compared to Arabic songs (Anis n.d., 8). This modern treatment of Arabic linguistics adds a new dimension to Arabic phonetics and phonology. Classical and medieval Arabic grammarians such as al-Khalīl al-Farāhīdī (170 AH/786 CE), Sībuviyē and Ibn Jinni $(392 \mathrm{AH} / 1002 \mathrm{CE})$ have already initiated the study of points of articulation (makhārij al-hurüf) where the vocal tract of man is divided into several areas and points according to the articulation or other classifications of the speech sounds of classical Arabic. In addition, Ibn Jinn̄i in his Sirr Șinā 'at al-I'rāab remarked on the influence of a letter sound to the neighbouring one when a string of sounds is vocalised (1993, 6-9). Subsequently, Ibn Sīnā (428 AH/1037 CE) by the virtue of his interest in anatomy provided a study on the generation of sounds which is phonetic as well as anatomic of the throat and the tongue 
(n.d., passim). His specific reference to the function of implosive and explosive movements of air resulted in his Risālat Asbāb Hudüth al-Hurūf to uniquely treat the three folds of sounds; production, acoustics and auditory (Al-Fayyūmī 1991). The interconnectedness of these subjects is somehow intricate, yet its presence is undeniably recognised. Ibn Jinnī himself has made a reference in al-Khașa 'iș $(1952,371)$ to the notion of tanghim as he explained that the omitted adjective in the sentence such as كان والله رجلا! (He is, BY ALLAH, a man) is retrievable through the recognition of high pitch in the word Allah and the lengthened sound of lām in it. It is as if the person is saying, "He is, BY ALLAH, a great man!" or "a brave man!" Ibn Jinnī argued that tatwīh (accentuation), tatrīh (rise), tafkhìm (euphuism) and ta zim (exaltation) could be sensed sometimes in the speech of a person which justifies the omission of certain adjectives. It is also worth noting that the science of tajwid has recorded several discussions about waqf (stopping) and saktah (breathless pause) where the beauty of recitation is related to the timing and the movement of air.

Eventually, the modern Arabic linguistic treatment of tanghim does labour more attention to the study of intonation and voice variations, since that modern linguistic has defined intonation as the variations in the pitch of voice, i.e., the variations in the pitch of the musical note produced by vibration of the vocal chords (Jones 1976). Although languages can be divided into lughät naghmiyyah (tonal languages) and lughät tanghimiyyah (intonation languages), all languages are subjected to the natural intonation or al-tanghim al-tabi $i \grave{i}$ that is devoid of any intonation-and-meaning functions yet allows its speaker to converse according to the sound system of the language (Al-Hāzimī 2009). Nevertheless, the ultimate aim of any linguistic study, as highlighted by the linguist Tammam Hassan (1994), or any prosodic analysis as propounded by the pioneer John Firth (d. 1948), rests in seeking a connection between phonology and the study of meaning. David Crystal $(1976,195)$ assertively maintained:

Scholars have been anxious to restrict the formal definition of intonation to pitch movement alone (though occasionally allowing in stress variation as well); but when the question of intonational meaning is raised, then criteria other than pitch are readily referred to as being part of the basis of a semantic effect.

Earlier, he stressed that, "intonation is not a single system of contours or levels, but the product of the interaction of features from different prosodic systems - tone, pitch-range, loudness, rhythmicality and tempo in particular" (Crystal 1976, 195). 
In a nutshell, whether classical and medieval Arabic linguistic thought harboured a systematic thought of tanghim or not has been a matter of debate amongst modern Arabic linguists ('Awad and $\mathrm{Na}$ 'âmeh 2006). It is interesting to note that the development of early Arabic linguistic thought has been observed to correlate the development of Qur' anic reading sciences (Shah 2003a, 2003b). What interests this research is the awareness to the various perspectives of tanghim or prosodic realisation and its semantical function in the comprehension and the deliverance of Arabic speech, particularly the Prophetic hadith. In other words, if the function of intonation is identified in Arabic linguistics in two categories, wazîfah adā'iyyah (syntactic role) and wazîfah dilāliyyah (semantic role) (Al-Hāzimī 2009), the present survey attempts to see the connection between the two roles within the context of hadīth studies.

\section{The Concept of Voice in Hadīth Theoretical Treatises and Modern Studies}

Although the concept of $a d \bar{a}$ ' has been treated in classical Arabic linguistic thought, the classical hadīth sciences took a different route when discussing the term ad $\bar{a}$. Under the topic of al-tahammul wa al-ada ' (reception and transmission), one will find elaborate discussion on the use of terms such as hadartu (I attended), sami 'tu (I heard), haddathanā (he narrated to us), akhbaranā (he informed us), ajāza lan $\bar{a}$ (he granted us the permission to narrate), etc., by a rāwi (transmitter) during the transmission of hadīth. This reflects the immense attention towards the sanad (chain of transmission) and its continuity laboured by the scholars of hadìth in attending the subject of $a d \bar{a}^{\prime}$ ' or ta'diyah (literally: fulfilment) in hadith . The Prophetic hadith that says, "God makes radiant those who heard our article, recognise it, safeguard it, and transmit it to others in the same form that he heard it (addāhā kamā sami 'ahāa)", was discussed in the sense of whether the paraphrasing of a hadīth text is allowed or not. Never was the phrase "addāha kama sami 'aha" explained in relation to the Prophet's tone in his speech. A dedicated study on this hadīth from both the riwāyah and dirāyah (transmission and interpretation) perspectives was carried by 'Abd al-Muhsin al- 'Abbād (1981), yet he left no single clue on whether any classical scholars of hadìth touched upon the subject of the Prophetic intonation. It is evident that $a d \bar{a}^{\prime}$ was understood by hadìth scholars in the sense of the deliverance that secures the physical structure of the text rather than the sonic voice of the text.

Another discussion under the topic of $a d \bar{a}^{\prime}$ was the conditions of ta'diyah. Some of these include 'adālah (uprightness) and dabt (memory). A number of scholars extended the discussion to the status of hadith reported by a non-believer, a young kid, a woman, etc. The subject of ad ${ }^{\prime}$ ' in hadith theoretical treatises could be said to focus on preserving the exact textual form of the hadith as possible as one can, 
without serious consideration given to the performance of the speech. This can be explained by the text-based framework of Muslim jurisprudence and legal practice that underlies the development of hadith systematic criticism. Even the attainment of superior $i s n \bar{a} d$, al-isnād al- 'âli or isnäd with lesser number of intermediaries whose justification is to be as close as possible to the original source of the speech, namely the Prophet, was not expounded in the sense of obtaining the most accurate tone of the speech sound.

This research has since ventured into finding clues to the subject of voice and intonation in the theoretical treatises of hadìth criticism. Unfortunately, from among 100 treatises on 'ulüm al-hadìth and muștalah al-hadìth, the search has yielded no effective result. The search has also included a careful examination of discussion in prominent works such as Ma 'rifat 'Ulūm al-Hadīth by al-Ḥākim al-Naysāūrī, al-Kifāyah fì Ușūl 'Ilm al-Riwāyah by al-Khațīb al-Baghdādī, Al-Muqaddamah by Ibn al-Șalāh, Tadrīb al-Rāwì by al-Suyūțī, Fath al-Mughìth by al-Sakhāwī and contemporary works such as 'Ulüm al-Hadìth Așìluhā wa Mu 'āșiruhā by Abullais al-Khayrabādī and Tahrī̄ 'Ulūm al-Hadìth by Abdullah al-Judaie.

The search was further extended to digital books. The researcher has organised approximately 250 treatises on the theoretical aspects of hadith criticism and sunnah studies in a digital software named al-Maktabah al-Shamilah. The first attempt was to search for the root نَ نَ (to intone) and its significant derivatives such as the word النغمة (tone), with and without the definite marker ال, the word التنغيم, and the word النغ within this collection. As foreseen, the software gave no significant result. The next attempt was to look for the word صوت (voice) and its derivatives within the same corpora. The software provided several results, but none were related to the subject of intoning a hadith text.

The third step of this survey was to look for a study that treats both phonetics and hadith studies available on the world wide web. The main website that was referred to is http://b7oth.com whose main page is titled Jämi 'al-Buhüth wa alRasā'il al- 'Ilmiyyah. The web was assessed on 15 September 2018. Similar to the previous attempts, the search yielded no significant result. The closest treatise one may consult on this subject is a doctoral dissertation titled Al-Asālīb al-Talabiyyah wa Adā'ātihā al-Iblāghiyyah fì al-Hadīth al-Nabawī: Muqārabah Tadāwuliyyah (Instructional Styles and Its Rhetorical Expressions in the Prophetic Hadith: A Pragmatic Analysis) which was submitted by Hamidat Djemai (2015) at Mohamed Lamine Debaghine Setif 2 University, Algeria. Djemai studied the performative modes (as opposed to informative modes) found in the rhetoric of hadith. The subject dragged the author to study the interrogative (istifhamm), positive imperative (amr), prohibitive or negative imperative (nahy), vocative (nida ${ }^{\prime}$ ) and optative 
(tamanni $)$ styles in hadìth texts as well as the role of context in the deliverance $\left(a d \bar{a}^{\prime}\right)$ of its message. However, little has been said by the author on the relationship between these functions and the intoning process of the hadith.

Another relevant study to this research is the article presented by Farha al-Sharīdi (2015) of Sirte University titled Al-Tahlīl al-Fūnīmì li al-Khițāb al-Nabawī: Dirāsat Șawtiyyat Maqta iyyah fì Khuțbat al-Wadā'. Al-Sharīdī performed a phonemic analysis on the last sermon of the Prophet Muhammad as recounted in al-Sìrah al-Nabawiyyah of Ibn Hishām. Her aim was to analyse the use of various syllables that consist of various onsets and rimes, viz. nucleus and coda, in the speech of the Prophet. Although her paper focused more on the phonemic and syllabic patterns of the sermon, al-Sharīdi did assert that the subject plays a vital role in the process of intonation and the study of voices that will affect the interpretation of the speech. While tracing the idea of syllable amongst the classical scholars, al-Sharīdi managed to present the definition of maqta ' or syllable according to al-Jāhịiz, al-Fārābī, Ibn Sīnā and Ibn Jinnī. However, despite her claim that hadith represents the best of Arabic speech and the aesthetic of its rhetorical strategies constitutes the ideal of illustrious human speech, al-Sharīdi did not inform us of any treatment of the subject by hadith scholars. On top of that, she admitted that studies on the linguistic dimension of hadith are rather exiguous and invited the readers to build further on her enterprising attempt.

The finding above corresponds well to Mustafa Shah's (2011) writing on "The Language of Hadith" presented in the Encyclopaedia of Arabic Language and Linguistics. The main issue that was raised by him in tackling the subject was the debate on paraphrasing a hadīth text or al-riwāyah bi'l-ma'nā. As for the grammatical citation and the linguistic value of hadìth, Shah detailed an extensive debate on the topic and concluded that:

The marginalisation of the language of hadith in the realm of grammatical citation has tended to obscure both the attention the corpora received in the works of early and medieval grammarians, as well as its use for the purpose of exemplification in other areas of early and medieval linguistic thought. (Shah 2011)

One important aspect remains to be considered, namely, has any of the interpreters of hadìth alluded to the significance of tone in the understanding of hadith across those extensive commentary works of hadith? The present study has not yet covered the commentaries in its gauging of the subject. The tradition requires more attention in the academia. According to Joel Blecher (2018): 
The field of hadith studies has largely overlooked the rich and extensive tradition of hadìth commentary (sharh al-hadìth), even as a handful of short articles and book chapters have begun to draw attention to the commentary tradition's value as a key hub of Islamic social and intellectual life over the past millennium ... hadìth commentary has remained hidden in plain sight.

Much more need to be done before the possibility of finding the connection between Arabic linguistic thought and hadith commentaries can be learned constructively.

\section{The Effect of Intonation on the Deliverance and the Understanding of Hadith}

In recognising the effect of intonation in the understanding of hadith, the present study has chosen a number of hadith texts and hypothesised the effect of different intonations in communicating its multifaceted functions. It is worth noting that earlier scholars of Arabic medieval thought have also specifically pointed out subjects such as the occurrence of ellipsis in hadith text that can be recognised through a certain intonation. For example, the hadith text reported in one of the manuscripts of Șậị̆ al-Bukhārī (hadīth no. 1485) spelled:

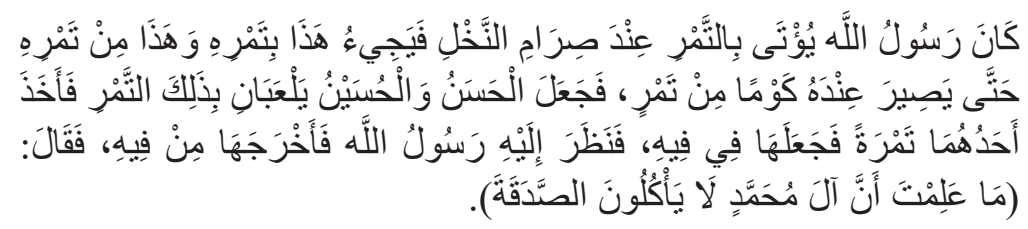

Meaning:

Dates used to be brought to the Messenger of Allah immediately during the plucking season. Different individuals would come with their dates until a big heap was gathered [as a charity for those in need]. Once al-Hasan and al-Husayn [the grandchildren of the Messenger of Allah] played with those dates and one of them took a date and put it in his mouth. The Messenger of Allah looked at him and took it out from his mouth and said, "[Don’t] you know that Muhammad's family do not eat from the charity[?]

In the course of reconciling between the version that reported it with ما علمت (You know that) and the one that reported it with أما علمت (Don't you know that), Ibn Mālik $(1992,146)$ in Shawāhid al-Tawḍ̄h stated that those who omitted the prefix, namely, hamzah al-istifhām (the interrogative particle) understood that it is 
indubitably preserved by implication (taqdīr) without which the meaning will be incoherent. According to 'Awad and $\mathrm{Na}$ 'àmeh (2006), the actual identifier for this implied hamzah al-istifhām is the intonation of the speaker.

The following 1-4 functions will further reinforce this impression:

1. Discerning the level of imperative.

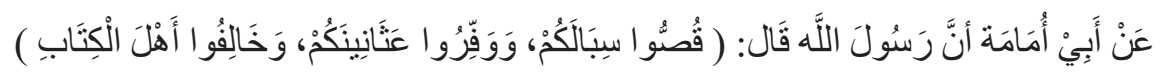

This hadith is reported in Musnad of Ibn Hanbal (2001, no. 22283) with this exact wording on the authority of Abū Umāmah RA. Should it be read with a rising tone and faster tempo from the word qușs $\bar{u}$ till the word al-kitāb, the meaning will be rendered: "Trim closely your moustache, let your beard grow and act against the People of the Book!", whereas a reading with the falling tone and slower tempo would suggest the meaning to be that the Messenger of Allah said: "You may trim closely your moustache and you may let your beard grow, and [by doing so, you can] be different from the People of the Book".

The second intonation would be more convincing if the whole text is to be observed. The hadith reads:

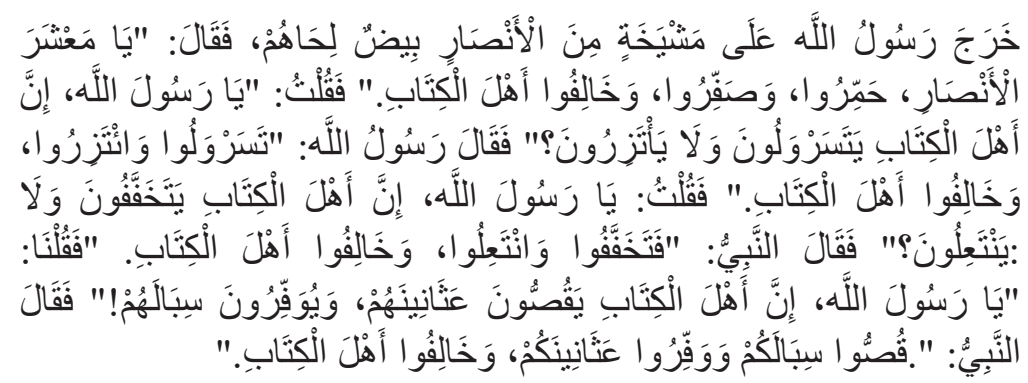

Although the literal translation would be different, the second intonation would suggest the following:

The Messenger of Allah came across some Anșār seniors whose beard has turned white. He said to them: Why don't you change the white into red or yellow, and be different from the People of the Book? I said: O Messenger of Allah, the People of the Book would wear pants, but they thought that it is forbidden to wear sarong. The Messenger of Allah replied: You may wear both pants and sarong and be different from the People of the Book. I said: O Messenger of Allah, the People of the Book would wear leather socks, but they thought that it is forbidden to 
wear sandals. The Messenger of Allah replied: You may wear both the leather socks and the sandals and be different from the People of the Book. We said: O Messenger of Allah, the People of the Book would trim closely their beard and let grow their moustache. The Messenger of Allah replied: "You may trim closely your moustache and let your beard grow and be different from the People of the Book". [Ibn Hanbal 2001, hadìth no. 22283]

2. Discerning a question from a statement.

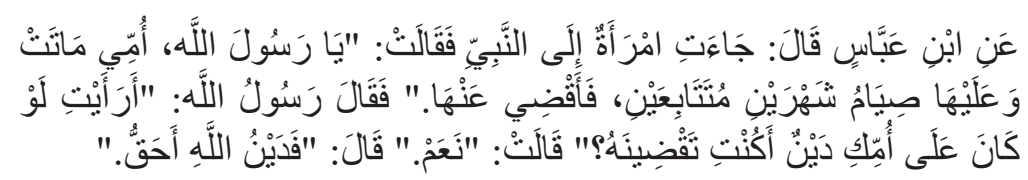

Ibn 'Abbās related that a woman came to the Messenger of Allah and said: “O Messenger of Allah, my mother died, and she hasn't fulfilled her duty to fast two months consecutively. I fulfilled them on her behalf [literal translation]". The Messenger of Allah asked: "Suppose some debt was due from your mother, would you pay it?" She replied: "Yes". He said: "The debt of Allah deserves more that it should be paid".

This hadīth was recorded by al-Ișfahānī in Al-Musnad al-Mustakhraj (1996, hadīth no. 2605). In the text, the woman's statement فَأَفِضِي عَنْهَ (I fulfilled them on her behalf) is originally a question, but the interrogative particle was omitted. Only a rising tone will suit this last part of her statement. By the virtue of the tone, a listener will immediately understand that the implied statement is أفأقضي عنها؟ (Should I fulfil them on her behalf?). The grammatical structure of the statement and the reply from the messenger in this regard are secondary. Further investigation will also reveal that other versions of this hadith reported in the form of an interrogative sentence. Nevertheless, in this specific version of the hadith, it was the ineluctable intonation that essentially gave the idea that the woman was asking a question.

3. The discourse function of hadith intonation.

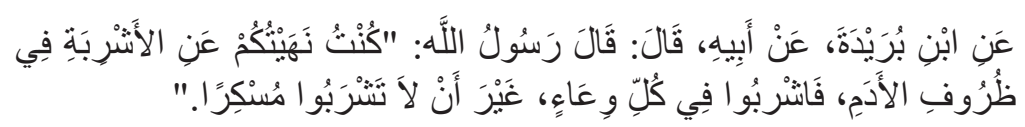

Ibn Buraydah, on the authority of his father, reported that the Messenger of Allah said: "I had forbidden you from the drinking (and preparation of) nabidh in the vessels made of leather, but now you may drink in all vessels, but you do not drink an intoxicant". 
The above hadīth was recorded by Muslim in Al-Musnad al-Șahịh (Al-Naysābūrī 1954, hadith no. 2001). The part from "kuntu" until "al-adam" is spoken with a lower pitch, a narrow range of pitch, a faster tempo and a lesser loudness to indicate that the information is marginal and already known to the listener. The new commandment in this hadith is the permissibility of drinking in all vessels. Through the contrasting intonation, listeners will be able to recognise the new information as well as the main clause in the speech.

4. Providing a better chance of comprehension and preservation of knowledge.

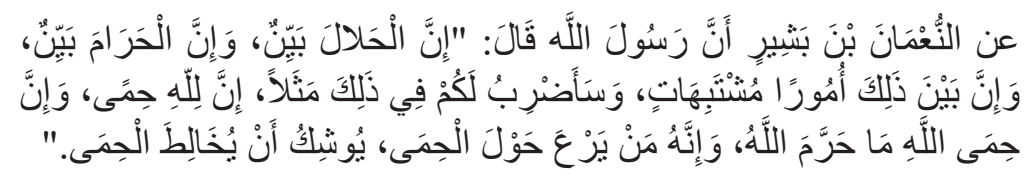

Al-Nu'mān ibn Bashīr reported that the Messenger of Allah said: "The lawful is clear, and the unlawful is clear, and between that are matters that are of resembling nature. I will give you an analogy. Allah has a sanctuary. Allah's sanctuary consists of what he has declared unlawful. If someone grazes (his animals) around a sanctuary, he would soon wind up in it".

The hadith with this exact wording is recorded in the hadīth fascicle of al-Anșārī (1998, hadith no. 25). The monotonous reading of the statement would surely make it difficult to grasp, but giving the suitable pitch, tempo and loudness demands that the speech be read with several stops. With the help of the rhyme found in the speech, the hadith could be divided into the following pieces:

\author{
Inna al-haläl bayyinun, \\ Wa inna al-harām bayyinun, \\ Wa inna bayna dhālika umūran mushābihātin, \\ Wa sa-adribu lakum fí dhālika mathalan. \\ Inna lillāh hịimā, \\ Wa inna himā Allah mā harrama Allah, \\ Wa innahu man yar'a hawl al-himāa, \\ Yūshiku an yukhālița al-himāa
}

This breaking of the hadith into several pieces makes it easier for the listener to grasp the meaning and additionally memorise the speech. As Wells (2006) has already declared concerning the psychological function of intonation: 
Tonality helps us to organise speech into units that are easy to perceive, memorise and perform. We can all repeat an arbitrary string of three, four and five numbers, but not a string of ten - unless we split them into two units of five.

All the above represents how the act of conscious intoning of hadith fulfils several functions formulated initially in English linguistic musings of the subject of intonation. As for the indexical function, viz. the intonation that provides the information of the context, the background, or the social identity of the speaker, it is quite difficult to find a suitable candidate for the exemplification purpose from the hadith corpora. Essentially, Tench $(2011,151)$ in his study on English intonation asserted that the indexical function of intonation does not directly affect either meaning or paralanguage, but rather manifests at the transmission stage of communication. Nevertheless, he does not deny the possibility that the addressee may evaluate the message in relation to the identity of the messenger. However, that falls in the sphere of the addressee's personal knowledge which is beyond the linguistic description.

\section{Potential Contributors to Arriving at the Appropriate Intonation}

Given the crucial role of intonation as illustrated in the previous section, the natural response of an observant Muslim towards this subject would be an attempt to find a way to learn the proper intonation that can be applied to the hadith texts. It is simultaneously a challenge for the scholars of hadith to vet this aspect of the discipline while they were well informed that no single hadith has ever been transmitted together with its tone. The previous review of hadith literature has also buttressed this fact. Some prominent adhān callers were said to have distributed ijāzah (permission certificate) to intone a mode of adhān that was narrated with a continuous sanad to the Companion of the Prophet, Bilāl ibn Rabāh, who was the first mu'adhdhin (caller to prayer) (Al-Muqaddim 2015; Laissani 2016). Some has even arranged a talqin (auditory learning) session to transmit the shar $i$ adhān (religious call to prayer) that is based on the principles of Islamic liturgical practices. ${ }^{1}$ Nevertheless, this was taken by some scholars as belonging to the domain of musalsal (serial mode) hadith where most of them were evaluated as da îf (weak) hadìth (Al-Nawawī 1985, 87; Ibn al-Ṣalāḥ 2006, 197; Ibn al-Mulaqqin 1988, 19). In most cases, the tone that was transmitted in those narrations was reproduced based on several conditions inferred from the Islamic injunctions, not the exact tone that was inherited in a form of echomimetic enterprise.

The Arabic classical transmission-based literature also does not give us much hope to find examples for tone preservation. Some instances, however, do reflect the attempt to communicate the tone of some words or texts. Ibn Muflih in his 
Al-Maqșad al-Arshad (1990, 66) related that Ahmad ibn Hanbal was asked concerning the melodious recitation of the Qur' an. Ibn Hanbal asked the inquirer: "What is your name?" He replied: "محمد (Muhammad)". Ibn Ḥanbal then remarked: "Would you be happy if people call you موحامد (Mūhāmād) lengthening every syllable sound?"

Thus, the tone of words or texts was occasionally indicated by the inclusion of additional vowel or the elongation symbol ( $a l-m \bar{a} d d)$ such as $(\sim)$. It denotes an elongation that is longer than a regular elongation. In the following hadith, this symbol is used to convey the tone of recitation applied by the Prophet.

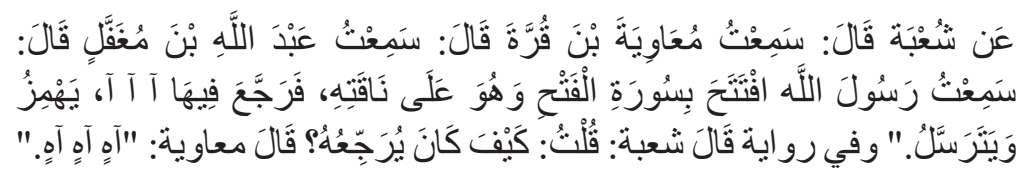

Shu'bah said; I heard Mu'āwiyah ibn Qurrah said; I heard 'Abd Allah ibn Mughaffal said: "I heard the Messenger of Allah reciting Sūrah al-Fath while he was on his camel ride. He recited it in $\operatorname{tarjī}^{\prime}$ (a vibrating and pleasant voice), such as a sound of $\bar{a} \bar{a} \bar{a}$ repeated thrice, making clear the sound of hamzah (a:) and lengthening it". In another version of this narration, Shu 'bah was reported to ask: "How does the tarjī' sound?" Mu'āwiyah replied: “Āh āh āh”. (Ibn al-Ja'd 1990, hadīth no. 1112)

Such an absence and unavailability forced the intonation process to operate within the domain of personal ijtihäd (to exert oneself industriously in requesting the knowledge of a certain subject). Several tools which are required for this task must be posited especially those skills and masteries that are related to hadith criticism. The present survey will highlight a number of contributors that may assist a reader in arriving at the most appropriate intonation of a hadìth text.

1. The study of uncommon words in hadith.

Known as the science of gharìb al-hadìth, the knowledge of this subject helps in the fluent pronunciation of peculiar words and phrases in hadith. Some manuals such as Gharīb al-Hadīth of Abū 'Ubayd and Al-Nihäyah fì Gharīb al-Hadīth wa al-Athar of Ibn al-Athī are useful for further investigation. The hadith such as: (What is evil in a man are alarming niggardliness and unrestrained cowardice) (Abū Dāwūd 2009, hadīth no. 2511) would be easier to enunciate if the word $h \bar{a} l i$ ' is learned beforehand. 
2. The study of al-amthāl al-nabawiyyah (Prophetic proverbs).

Hadith corpora are replete with proverbial forms as proffered by compilers such as al-Ḥakīm al-Tirmidhī (c.320 AH/932 CE), al-Rāmhurmuzī (360 AH/971 CE), and Abu'l-Shaykh al-Isfahānī (369 AH/980 CE) although they differed slightly in defining amthāl either as proverbs or similitudes. Familiarity with the proverbial forms will undoubtedly accelerate the comprehension and reading skill. An example of this kind can be learned in the following haditth:

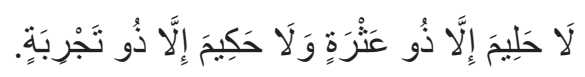

No one is forbearing unless he himself has made a mistake. No one is wise unless he himself has lived through experiences. [Ibn Hanbal 2001, hadith no. 11056]

The recognition of rhyme contributes towards the best intonation in addition to the familiarity with various forms of proverbs, idioms, similes, metaphors and the likes in hadith corpora.

3. The study of Arabic rhetorical strategy devised in the hadith.

Apart from the Qur'ān and poetry, Arabic rhetoric literature has also consulted hadīth in establishing some principles of rhetoric (Al-Jarbī 2012). Al-Jarbī indicated that the Prophet's fluency and high aesthetical flavour in language have been the subject of many studies. In fact, the presence of any cacophonic words or ineloquent qualities in a riwäyah (narration) would be taken as a sign of an apocryphal or fabricated hadīth (Ibn Qayyim 1998, 79). Al-Jurjānī (1991) in his demonstration of several elements of rhetoric in Asrār al-Balaghāh (p. 113) devised a number of hadiths. As an example, he cited the following hadīth:

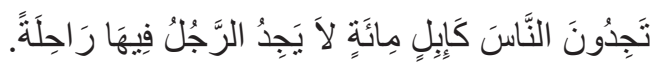

You would find people like one hundred camels and you would not find even one (camel) fit for riding. (Al-Naysābūrī 1954, hadīth no. 2547)

According to him, the principles and components of Arabic metaphor are clearly adhered to and well observed in hadìth texts. Ultimately, rhetorical preference impinges upon an intoning exercise and this has also been successfully established in some studies (El Zarka 2017). It is not far-fetched then to conclude that the study of Prophetic rhetoric will contribute significantly to the identification and deliverance of the appropriate intonation of hadìth. 
4. The study of al-nāsikh wa al-mansükh (abrogation) in hadīth literature.

As illustrated in the above-mentioned explanation on discourse function of intonation, certain falling and rising in tone would indicate that a novel fact is being introduced to the listener. Inversely, the knowledge of the abrogated and the abrogating matters in hadith contributes in finding the best intonation for any hadith text that is relevant to the discussion.

5. The study of sabāb wurūd al-hadìth (the hadīth background).

The study of the socio-historical background of any Prophetic tradition, or in a broader sense, the context of the hadith, has been attracting more researchers to uncover its importance and consequences in modern times. However, most of these researches have been focussing on its role in the course of hadith interpretive pursuits (Al-'Awnī 2017, 8). The present study, uniquely and unconventionally, suggests that intonation can affect the listener's understanding of any injunctions or statements carried in a hadìth text. To prove this point, the following hadīth should be explicated.

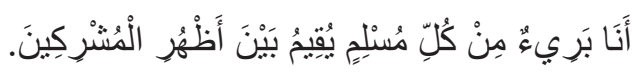

One may intone this hadith with a high pitch, a slower speed, and an amplified loudness to impress the meaning, "I disown every Muslim who lives among the polytheists". On the contrary, one may read it in a low pitch, a falling tone, a tremulous voice or a slower tempo, where the meaning could be rendered as, "I am not responsible for any Muslim who stays among the polytheists", or "I am not obliged to pay the full blood money for any Muslim who stays among the polytheists".

The difference between the two meanings is significant for the former implies a general and universal declaration while the second alludes to a specific event. The intonation highly plays a role in communicating each meaning. However, the second rendition could be preferred and more convincing when the background of this statement is learned. A more complete narration of this hadith read as what follows:

Jarī b. 'Abd Allah is reported to have said that the Messenger of Allah sent a battalion to the tribe of Khuth 'um. Some of the members of the tribe sought salvation in performing prostration (to mark themselves as Muslim). However, the battalion hurriedly killed them (while doubting their acts). When the Messenger of Allah heard of this, he ordered their families to be paid half the amount of blood money and said, 
"I am acquitted of every Muslim who lives amongst the polytheists". We asked, "Why is that, O Messenger of Allah?" He replied, "You could not distinguish between their two fires (i.e., between who were Muslims and who were non-Muslims)". (Abū Dāwūd 2009, hadīth no. 2645)

Hence, one may conclude that any speaker or reader of hadith should consult the sabab wurūd references to ensure the right impression is gained before delivering a hadith to the public or any relevant group.

\section{The study of ta 'addud al-riwāyāt (multiple narratives) of a hadīth}

Another phenomenon that requires serious attention in the field of hadith is the occurrence of diverging versions of a certain Prophetic tradition. It is not in the scope of this article to address the nature and essentials of this subject. Many treatises have deliberated on the issue. What concerns the present study is that the awareness of the multiple narratives of a certain text can affect the intonation of the text particularly in the sense that the level of voice corresponds faithfully to the level of confidence in the speech text. The more confident a reciter in the reconcilability of the variations in the text, the more convincing the intonation will form. Take an example the following hadìth:

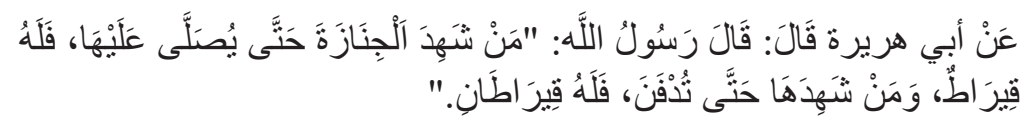

Abū Hurayrah reported that the Messenger of Allah said, "Whoever follows the funeral procession and offers the funeral prayer for it will get a reward equal to one qì $\bar{a} t$, and whoever attends it till burial will get a reward equal to two qīrāts". (Al-Bukhārī n.d., hadìth no.1325)

No issue amongst the hadìth scholars was reported in the classical hadìth literature concerning this hadith. At first glance, a reciter may have no problem in delivering this hadith to his audience. However, if a thorough study was carried off the history of the transmission of the hadith, several other versions will surface.

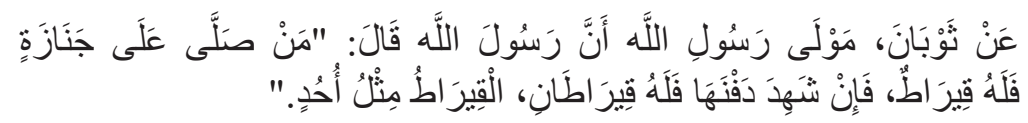

Thawban, the servant of the Messenger of Allah reported that the Messenger of Allah said: "He who offered prayer for the dead, for him is the reward of one qì $\bar{a}$ t, and he who attended its burial, he would have two qīràts as his reward. A qīrât is equivalent to the mountain of Uhud". (Al-Naysābūrī 1954, hadīth no. 949) 
The reciter, here, is faced with additional information. This will either increase his confidence of the content or decrease it in the sense that some missing elements have been discovered and realised. The other version of this hadith reads:

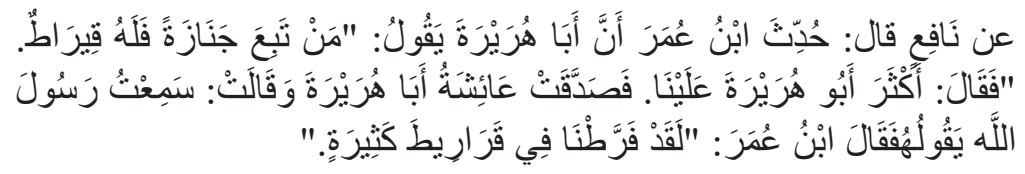

Nāfi' related: Ibn 'Umar was told that Abū Hurayrah said, "Whoever accompanies the funeral procession will have a reward equal to one qīrât". Ibn 'Umar said, "Abū Hurayrah talks of a too enormous reward". 'A' ishah attested Abū Hurayrah's narration and said, "I heard the Messenger of Allah saying the same". Ibn 'Umar said, "We have missed numerous qīrāts"s. (Al-Bukhārī n.d., hadìth no. 1324)

By studying multiple versions of a hadith narration and observing conformity and conflict within them, a reciter of hadith would be able to gain control over his confidence and deliverance. Although all sub-areas in the science of dirāyat al-hadith (interpretive discourse) would affect the process of understanding and intoning a hadith text, the present study has limited its elaboration to selected prominent areas to suit the preliminary status of this library survey. It is glaringly obvious that the act of takhrijj (hadith retracement) constitutes the most important key to the learning of all the above-mentioned issues.

\section{Conclusion}

The interplay of intonation and hadith text in this library survey has shown that the former is not simply a linguistic phenomenon but also a manifestation of a cognitive phenomenon while the latter owns some aspects of its interpretive function to the former. This preliminary survey in the relevant literature has revealed that the subject received too little attention either by the Arab linguists or even the hadith experts themselves. Thus, the formulation of a systematic framework to locate all aspects of the discussion is considered unattainable for the time being. The present theoretical venture has also demonstrated that hadith intonation plays a vital role for both the narrator and the listener. As for the narrator, it contributes in terms of performance, fluency, confidence, as well as faithful and devout transmission of the Prophetic statement. As for the listener, intonation contributes in the making of appropriate imagination of the Prophetic speech and the conveyance of the apposite meaning of the texts. The study of hadith intonation, therefore, informs our exploration of hadith interpretive discourse and by extension adds a new dimension to the epistemological enterprise of hadith studies. Some practical 
applications include the awareness of the listeners to the extreme manipulation of hadith text through certain intonational exaggeration and elements of hateful speech. On the other hand, several issues such as the singing of hadith and certain words of remembrance ( $a d h k \bar{a} r$ ) narrated in the hadìth can be addressed through well-developed arguments and discourse. It is, therefore, incumbent upon the experts of Arabic linguistics and the experts of hadith to work out a systematic study of what may be termed hadīth phonology or hadìth linguistic thought. The effects of intonation on the listeners can also be investigated and analysed through systematic fieldwork analysis. Since hadith has special psycho-spiritual effects amongst the observant Muslim community, the study of intonation in the deliverance of hadith is a necessity for the community's social security and its civilisational endeavours.

\section{Acknowledgements}

The author would like to thank International Islamic University Malaysia for the research grant provided under the Research Initiative Grant Scheme (RIGS), with the project number RIGS17-121-0696.

\section{Notes}

1. Retrieved from Talqīn al-Shaykh Dr. Ilyas al-Adhān al-Shar'ī (2012), https://www. youtube.com/watch?v=t3EHgBexMiM (accessed 1 October 2018); and Adhān alAlbānī(2011), https://www.ajurry.com/vb/attachment.php?attachmentid=13777\&d= 1315259483 (accessed 1 October 2018).

\section{References}

Abū Dāwūd, Sulaymān ibn al-Ash 'ath. 2009. Sunan Abū Dāwūd, Kitāb al-Jihād (AlArna'ūt, Shu'ayb et al., eds.). Beirut: Dār al-Risālah al- 'Ālamiyyah.

Al-'Abbād, 'Abd al-Muhsin. 1981. Dirāsat Hadīth Naḍdara Allah Imra'an Sami'a Maqālatī ... Riwāyah wa Dirāyah. Madinah: Author.

Al-Anșārī, Muhammad ibn 'Abd Allah. 1998. Hadīth Muhammad ibn 'Abd Allah al-Anșārī (al-Sa 'danī, Mis 'ad, ed.). Riyadh: Aḍwà' al-Salaf.

Al-Bukhārī, Muḥammad ibn Ismā '̄il. n.d. Al-Jāmi 'al-Musnad al-Ṣaḥ̄ḥ al-Mukhtașar min Umūr Rasūl Allāh wa Sunanihi wa Ayyāmihi (Al-Bughā, Muștafā Dīb, ed.). Beirut: Dār Ibn Kathīr.

Al-Farisīi, Abū 'Alī al-Ḥasan ibn Aḥmad. 1993. Al-Hujjah li'l-Qurrā' al-Sab 'ah (Badr alDīn Qahwaj̄ì, ed.). Beirut: Dār al-Ma'mūn.

Al-Fayyūmī, Ahmad. 1991. Abhāth fì 'Ilm Așwāt al-Lughah al-'Arabiyyah. Cairo: Maṭba'ah al-Sa'ādah.

Al-Ḥāzimī, 'Ulyān ibn Muhammad. 2009. Al-Tanghīm fī al-Turāth al-'Arabī. Majallah Jāmi 'at Umm al-Qurā (23)1: 283-291. 
Al-Iṣfahān̄ī, Abū Nu'aym. 1996. Al-Musnad al-Mustakhraj 'alā Ṣah̄hh al-Imām Muslim (Al-Shāfi '̄i, Muḥammad Ḥasan, ed.). Beirut: Dār al-Kutub al-'Ilmiyyah.

Al-Jarbī, 'Abd al-Salām Muḥammad. 2012. Al-Ḥadīth al-Nabawī al-Aṣl al-Thānī min Uṣūl al-Iḥtijāj al-Balāghīm Dirāsat fī al-Manjaj wa al-Tatbīq. Majallah al-Jāmi 'ah alAsmarya (17)1: 281-318.

Al-Judaie, 'Abd Allah. 2005. Al-mūsīqā wa al-ghinā' fì mìzān al-Islām. Beirut: Mu'assasah al-Rayyān li'l-Ṭibā'ah wa al-Nashr.

Al-Jurjānī, 'Abd al-Qāhir. 1991. Asrār al-balāghah fì 'ilm al-bayān (Muhammad Shākir, Maḥmūd, ed.). Jeddah: Dār al-Madanī.

Al-Muqaddim, Ismā'îl. 2015. Ijāzah fī al-Adhān wa al-Iqāmah. http://almukaddem.com/ books/75/إجازة-في_الأذان-و الإقامة: (accessed 1 October 2018).

Al-Nawaw̄ì, Yahyā ibn Sharaf. 1985. Al-taqrīb wal al-taysīr li ma 'rifat sunan al-bashīr alnadhīr (al-Khisht, Muḥammad 'Uthmān, ed.). Beirut: Dār al-Kitāb al- 'Arabī.

Al-Naysābūrī, Muslim ibn al-Hajjāj. 1954. Al-musnad al-ṣahīḥ al-mukhtașar min al-sunan bi naql al- 'adl 'an al- 'adl 'an Rasūl Allah Șalla Allah 'Alayhi wa Sallam ('Abd alBāqī, Muhammad Fu'ād, ed.). Beirut: Dār Ihyā' al-Turāth al- 'Arabī.

Al-Sharīdī, Farha. 2015. Al-Taḥlīl al-Fūnīmī li al-Khițāb al-Nabawī: Dirāsat Șawtiyyat Maqta iyyah fī Khuṭbat al-Wadā’. Paper presented at Dirāsāt Șawtiyyah fì al-Lughah al-'Arabiyyah Conference. Dubai, UAE. Retrieved from http://www.alarabiahconference.org/uploads/conference_ research-358012338-1436347110-1192.pdf (accessed 1 June 2019).

Al- 'Awnī, 'Ādil. 2017. Asbāb Wurūd al-Hadīth: Mu'allafātuhu, Aqsāmuhu, Fawā’iduhu. https://www.alukah.net/Books/Files/Book_9349/BookFile/hadis.pdf (accessed 1 June 2019).

Anis, Ibrahim. n.d. Al-așwāt al- 'arabiyyah. Egypt: Maktabah Nahḍat Miṣr.

'Awaḍ, Sāmī and Na'āmeh, 'Ādel. 2006. Dawr al-Tanghīm fī Taḥdīd Ma'nā al-Jumlah al'Arabiyyah. Tishreen University Journal for Studies and Scientific Research (28)1: 87-109.

Blecher, J. 2018. Said the prophet of God: Hadith commentary across a millennium. California: University of California Press. https://doi.org/10.1525/ california/9780520295933.001.0001

Büring, D. 2016. Intonation and meaning. Oxford: Oxford University Press.

Crystal, D. 1976. Prosodic systems and intonation in English. Cambridge: Cambridge University Press.

Djemai, H. 2015. Al-Asālīb al-Ṭalabiyyah wa Adā'ātihā al-Iblāghiyyah fī al-Ḥadīth alNabawī: Muqārabah Tadāwuliyyah. PhD dissertation, Mohamed Lamine Debaghine Setif 2 University, Setif, Algeria.

El Zarka, D. 2017. Arabic intonation. In Oxford handbooks online, 1-37. Oxford: Oxford University Press. https://doi.org/10.1093/oxfordhb/9780199935345.013.77

Hassan, T. 1994. Al-lughah al-'arabiyyah, ma'nāhā wa mabnāhā. Morocco: Dār alThaqāfah.

Ibn al-Ja 'd, 'Alī. 1990. Musnad 'Alī ibn al-Ja 'd (Haydar, 'Āmir, ed.). Beirut: Mu'assasah Nādir.

Ibn al-Mulaqqin, 'Umar ibn 'Alī. 1988. Al-Tadhkirah fì 'ulūm al-ḥadìth (Hasan, 'Alī, ed.). Amman: Dār 'Ammān. 
Ibn al-Șalāḥ, 'Uthmān. 2006. Al-Muqaddamah (An introduction to the science of hadith) (translated by E. Dickinson). England: Garnet Publishing Ltd.

Ibn Hanbal, Ahmad. 2001. Al-Musnad (Al-Arna'ūt, Shu 'ayb et al., eds.) Beirut: Dār Ihyā' al-Turāth al-'Arabī.

Ibn Jinn̄̄, Abū al-Fatḥ 'Uthmān. 1952. Al-khaṣā'iṣ (Al-Najjār, Muḥammad 'Alī, ed.). Egypt: Dār al-Kutub al-Mișriyyah.

1993. Sirr șinā 'at al-i 'rāb (Hendawi, Hasan, ed.). Damascus: Dār al-Qalam.

Ibn Mālik, Jamāl al-Dīn al-Andalusī. 1992. Shawāhid al-tawḍ̄ḥ wa al-taṣhīh li mushkilāt al-jāmi 'al-șaḥ̄ḥ (Muḥsin, Ṭāhā, ed.). n.p.: Maktabah Ibn Taymiyyah.

Ibn Mufliḥ, Ibrāhīm ibn Muḥammad. 1990. Al-maqșad al-arshad fì dhikr aṣhāa al-Imām Ahmad (Al- 'Uthaymīn, 'Abd al-Raḥmān, ed.). Riyadh: Maktabah al-Rushd.

Ibn Qayyim al-Jawziyyah, Muḥammad ibn Abī Bakr. 1998. Al-manār al-munīf fì al-șah̄ịh wa al-ḍa īf (Al-Mu 'allimī, 'Abd al-Raḥmān, ed.). Riyadh: Dār al- 'Āṣimah.

Ibn Sīnā, Abū 'Alī al-Ḥusayn ibn 'Abd Allah. n.d. Risālah asbāb hudūth al-ḥurūf (Al-Ṭayyān, Muhammad Ḥassān, ed.). Damascus: Maṭbū'āt Majma`al-Lughah al- 'Arabiyyah bi Dimashq.

Jones, D. 1976. An outline of English phonetics (9th ed.). Cambridge: Cambridge University Press.

Laissani, M.A. 2016. Ijāzah wa Sanad fī al-Adhān al-Shar'̄. https://www.facebook.com/ photo.php?fbid=507914356077740\&set=a.105708526298327\&type=3\&theater (accessed 1 October 2018).

Musa, A. 2008. Hadith as scripture: Discussions on the authority of prophetic traditions in Islam. London: Palgrave Macmillan.

Nelson, K. 2001. The art of reciting the Qur'an. Cairo: The American University in Cairo Press.

Rasmussen, A. 2001. The Qur'an in Indonesian daily life: The public project of musical oratory. Ethnomusicology (45)1: 30-57. https://doi.org/10.2307/852633

Shah, M. 2003a. Exploring the genesis of early Arabic linguistic thought: Qur'anic readers and grammarians of the Kufan tradition (Part I). Journal of Qur'anic Studies (5)1: 47-78. https://doi.org/10.3366/jqs.2003.5.1.47

2003b. Exploring the genesis of early Arabic linguistic thought: Qur'anic readers and grammarians of the Bașran tradition (Part II). Journal of Qur'anic Studies (5)2: 1-47. https://doi.org/10.3366/jqs.2003.5.2.1

2011. The language of hadith. In Encyclopaedia of Arabic language and linguistics. Managing editors online edition, eds. L. Edzard, and R. de Jong, 10-32. Leiden: Brill.

Tench, P. 2011. Transcribing the sound of English: A phonetic workbook for words and discourse. Cambridge: Cambridge University Press. https://doi.org/10.1017/ cbo9780511698361

Wells, J. 2006. English intonation, an introduction. Cambridge: Cambridge University Press. 